\title{
Influence of prey behaviour and other predators on the foraging activities of a marine avian predator in a Low Arctic ecosystem
}

\author{
Gail K. Davoren ${ }^{1, *}$, Stefan Garthe ${ }^{2}$, William A. Montevecchi ${ }^{3}$, Silvano Benvenuti ${ }^{4}$ \\ ${ }^{1}$ Department of Biological Sciences, Duff Roblin Building, University of Manitoba, Winnipeg, Manitoba R3T 2N2, Canada \\ ${ }^{2}$ Research and Technology Centre (FTZ), University of Kiel, Hafentörn 1, 25761 Büsum, Germany \\ ${ }^{3}$ Departments of Psychology and Biology, Ocean Science Centre, Memorial University of Newfoundland, \\ St. Johns, Newfoundland A1B 3X9, Canada \\ ${ }^{4}$ Dipartimento di Etologia, Ecologia ed Evoluzione, University of Pisa, Via A. Volta 6, 56126 Pisa, Italy
}

\begin{abstract}
Air-breathing marine predators can expend considerable time and energy searching for patchily distributed prey and, thus, likely employ varying foraging strategies to minimize these costs. We studied the diurnal foraging patterns of the northern gannet Sula bassana along with the distributional patterns of its main prey, capelin Mallotus villosus, off the NE Newfoundland coast from 1999 to 2005. We explored whether gannets minimize searching costs for near-surface $(<30 \mathrm{~m})$ capelin by (1) aggregating in shallow waters $(<30 \mathrm{~m})$ where capelin are accessible throughout the day, (2) aggregating in deeper waters where they concentrate foraging effort at dawn and dusk, when diel vertical migrations make capelin accessible, or (3) associating with other marine predators that increase the accessibility of capelin. We integrated continuous recordings of gannet foraging activities with vessel-based survey data on the density and distributional patterns of capelin, gannets and whales. Capelin typically comprised $>70 \%$ of gannet diets. Gannets aggregated in shallow areas $(<30 \mathrm{~m})$ where spatially and temporally persistent shoals of capelin were accessible through daylight, but were also found in deeper water where capelin were inaccessible. Gannet diving activity was only recorded during daylight, and although activity peaked at the start and end of daylight, most dives occurred when capelin had migrated to inaccessible depths. Gannets were more tightly associated with whales than with near-surface capelin shoals, suggesting that they may successfully track capelin by cueing to the foraging activities of whales. A mixed strategy of memory-based and local enhancement foraging tactics appear to play important roles in minimizing the effort required to access prey.
\end{abstract}

KEY WORDS: Diet · Diel vertical migration $\cdot$ Whale-seabird associations $\cdot$ Memory-based foraging Local enhancement · Capelin

\section{INTRODUCTION}

In marine systems, predators can expend considerable time and energy searching for patchily distributed prey over vast areas of ocean. Air-breathing predators must expend more energy searching underwater, as they must regularly commute between the surface and prey at depth, possibly losing contact with prey in the process. To minimize energetic costs of searching, air-breathing marine predators may employ a variety of foraging strategies. There is growing evidence that marine predators may use a memory-based strategy to return to areas in the open ocean, where accessible, dense prey are temporally and spatially persistent (Norse et. al. 2005). Similarly, predators may concentrate foraging effort at certain 
times of day when prey are more accessible, such as at dawn and dusk when diel vertical migrating prey may be concentrated near the surface (Hays 2003). There is also growing evidence that predators cue to the foraging activities of other predators that may make prey more accessible near the ocean surface, as evidenced by numerous descriptions of multi-species feeding assemblages of birds, mammals and fish (Hoffman et al. 1981, Camphuysen \& Webb 1999), as well as experimental evidence of bird attraction to other predators (Porter and Sealy 1982) and fishing boats (Garthe \& Hüppop 1994).

Using one or many strategies to minimize search costs for prey may be especially important for marine predators that are restricted to feeding in surface waters. The northern gannet Sula bassana is the largest pelagic seabird in the north Atlantic (adult body mass = ca. $3 \mathrm{~kg}$; Nelson 1978) and populations are generally increasing, likely due to reductions in human-induced mortality (Montevecchi \& Myers 1997). Their foraging mode is characterized by plunge diving, whereby they plunge dive and then swim back passively to the sea surface, and by pursuit-plunging, whereby they plunge dive and then pursuit-dive thereafter, using bent wing flapping to propel themselves underwater (Garthe et al. 2000). They can also detect prey from the surface and dive without plunging (Ropert-Coudert et al. 2004). Gannets regularly dive up to $10 \mathrm{~m}$ deep (Garthe et al. 1999, 2003), with a maximum recorded depth of $34 \mathrm{~m}$ (Brierley \& Fernandes 2001). Diving profiles and maximum depths have been explained by prey species captured during the dive (Adams \& Walter 1993, Garthe et al. 2000). Gannets are visual foragers, and foraging activity has only been recorded during daylight (Garthe et al. 1999, 2000). Similarly, travel speeds associated with flight have generally not been recorded during dark periods (Garthe et al. 1999, 2000, Hamer et al. 2000, 2001, Lewis et al. 2002, cf. Garthe et al. 2003) except during migration (D. A. Fifield \& W. A. Montevecchi unpubl. data). Breeding gannets are opportunistic foragers on most pelagic prey species that are abundant within foraging ranges, with the consumption of certain species highly correlated with abundance indices and fisheries catches (Montevecchi \& Myers 1995). Therefore, diets during breeding indicate shifts in species composition of pelagic food webs (Montevecchi \& Myers 1996, Montevecchi 2007).

In the northwest Atlantic, the dietary composition of gannets shifted from warm-water, migratory pelagic fish (e.g. Atlantic mackerel Scomber scombrus, Atlantic saury Scomberesox saurus, and short-finned squid Illex illecebrosus) in the 1970s and 1980s to coldwater pelagic fish (primarily capelin Mallotus villosus, Atlantic herring Clupea harengus and Atlantic salmon
Salmo salar), associated with a centurially-significant cold water event in 1991 (Montevecchi \& Myers 1997). Capelin have remained the primary prey of gannets at the Funk Island Seabird Ecological Reserve through the 1990s and during the early 2000s (Montevecchi et al. 2005, 2009). During daylight within foraging ranges of this colony, capelin are associated with the seabed (Davoren et al. 2006), and thus, their vertical distribution is primarily determined by water depth. Predictable aggregations of capelin are persistent among years at shallow water $(<30 \mathrm{~m})$ demersal spawning sites and deep-water (100 to $150 \mathrm{~m})$ staging areas between the coast and Funk Island (Davoren et al. 2006). In deep water (>50 m), capelin migrate toward the ocean surface at dusk and back toward the seabed at dawn (Mowbray 2002, Davoren et al. 2006). We explored how gannets access capelin throughout daylight by investigating whether birds: (1) concentrate in shallow areas $(<30 \mathrm{~m})$, where capelin are accessible throughout the day, or use deeper areas and either (2) concentrate foraging effort during dawn and dusk transition periods, when capelin are accessible near the surface, and/or (3) associate with other marine predators that make prey accessible at the surface throughout the day. To examine which strategies may play important roles in gannet foraging behaviour, we combine continuous records of the gannets' foraging activities, with fine temporal scale quantitative data on the vertical distribution of capelin as well as the distributional patterns of gannets in comparison to capelin and to other predator species.

\section{MATERIALS AND METHODS}

Study design. The study design combined birdborne device recordings on the foraging activities of gannets with meso-scale, vessel-based survey data on the horizontal distributional patterns of gannets, other predators and capelin, as well as fine-scale survey data on the vertical movement patterns of capelin. Breeding northern gannets were studied from late July to midAugust (July 24 to August 12), 1999 to 2005 at their colony on Funk Island $\left(49^{\circ} 45^{\prime} \mathrm{N}, 53^{\circ} 11^{\prime} \mathrm{W}\right)$ off the NE coast of Newfoundland in eastern Canada (Fig. 1). Funk Island, a low-lying, flat granite rock ca. $400 \times$ $800 \mathrm{~m}$, is the site of the fourth largest and most oceanic colony of gannets in the western Atlantic. In all years, regurgitations of gannets were collected to determine dietary composition (Table 1). Archival data loggers were attached to gannets in alternating years (1999, $2001,2003,2005)$ to determine at-sea foraging behaviour (Table 1). A meso-scale survey was conducted in 2000-2003 to determine the distribution and density of gannets and other predators along with their main 
prey species, capelin, aboard the $23 \mathrm{~m}$ Fisheries and Oceans RV 'Shamook' in mid-late July (Table 1). The survey $(\sim 800 \mathrm{~km})$ was run within avian foraging ranges and prime capelin spawning and staging areas to the south and west of Funk Island (Davoren et al. 2006; Fig. 1). Nine east-west transects spaced $9 \mathrm{~km}$ apart on a north-south axis were run $12 \mathrm{~h} \mathrm{~d}^{-1}$, primarily during daylight (08:00 to 20:00 h Newfoundland Daylight Savings Time $=$ UTC minus $2.5 \mathrm{~h}$ ). Surveys were periodically interrupted to identify the species composition of
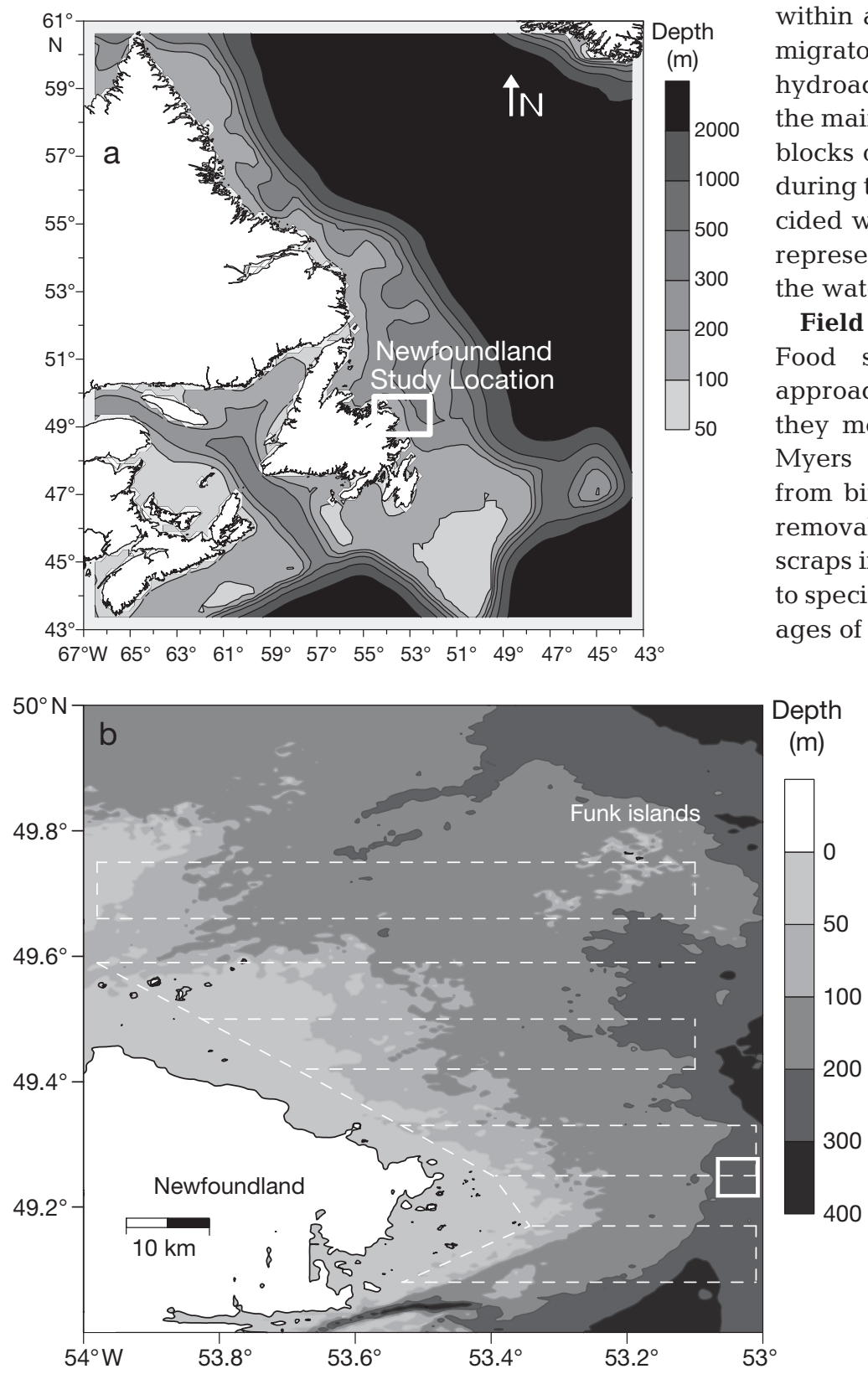

Fig. 1. Location of (a) the Newfoundland study in eastern Canada (white square) and (b) the meso-scale survey (white dashed line); fine-scale study site (white square); and Funk Island Seabird Ecological Reserve. Scale indicates the depth contours $(\mathrm{m})$ in the study area acoustic signals using a modified shrimp trawl (Davoren et al. 2006). Capelin were the numerically dominant fish species sampled (96.5\%; Davoren et al. 2006).

As part of another project (Davoren et al. 2007), the diel vertical movement patterns of capelin were studied during a 4 d fine-scale study (10 to 14 August, 2005; Table 1) aboard a $60 \mathrm{~m}$ Fisheries and Oceans Canada RV 'Wilfred Templeman.' The fine-scale site was centered on the area $\left(49^{\circ} 15^{\prime} \mathrm{N}, 53^{\circ} 02^{\prime} \mathrm{W}\right)$ where a large concentration of post-spawning capelin was found within avian foraging ranges (Fig. 1). To quantify the migratory patterns of capelin, we repeatedly collected hydroacoustic data along a radial survey $(\sim 30 \mathrm{~km})$ over the main concentration of capelin such that all $1 \mathrm{~h}$ time blocks over the $24 \mathrm{~h}$ cycle were sampled at least once during the $4 \mathrm{~d}$ study. Dates of the fine-scale study coincided with the deployment of devices on gannets and represent the timing of diel vertical migrations through the water column at dawn and dusk (Table 1).

Field work on northern gannets. Diet sampling: Food samples were obtained from gannets by approaching roosting birds that often regurgitated as they moved away from researchers (Montevecchi \& Myers 1995; Table 1). Samples were also obtained from birds captured for data logger attachments and removals and from discarded regurgitations and scraps in the colony. Regurgitated prey were identified to species, and prey landings are presented as percentages of total regurgitations during each year.

Bird capture and data logger attachment: Adult gannets with 4 to 6 wk old chicks in their nests were captured and later recaptured with a telescoping noose pole from a small portable blind to minimize disturbance to neighbouring birds. Birds were equipped with loggers, marked on the head and neck with colored markers for identification from a distance and banded with USFWS bands issued by the Canadian Wildlife Service usually within 5 to $10 \mathrm{~min}$. Over all years, 5 types of data loggers were attached to derive dive depth and duration from a pressure sensor over a range of 24 to 76 h (Table 1). Lotek LTD 100s were attached by Tesa ${ }^{\circledR}$ tape to 2 plastic bands placed on one leg of each bird. The other devices were attached with Tesa ${ }^{\circledR}$ tape to either feathers on the lower back about $5 \mathrm{~cm}$ above the uropygial gland or the 4 central tail feathers. Breeding success was high at the sites where we worked. After each gannet carrying a logger was recaptured, devices were removed quickly, and data were downloaded onto a laptop computer. 
Table 1. Sula bassana. Dates of vessel-based surveys and colony-based diet sampling and device deployments from $1999-2005$. For detailed device descriptions refer to Garthe et al. (2000, 2003, 2007a) and Montevecchi et al. (2009). n: number of northern gannets. -: years when no data were collected

\begin{tabular}{|c|c|c|c|c|c|c|c|c|}
\hline Year & $\begin{array}{l}\text { Vessel-based } \\
\text { surveys }\end{array}$ & Diet & $\begin{array}{c}\text { Device } \\
\text { deployment }\end{array}$ & Type & $\begin{array}{c}\% \text { body } \\
\text { mass }\end{array}$ & $\begin{array}{c}\text { Recording } \\
\text { interval }\left(\mathrm{s}^{-1}\right)\end{array}$ & $\begin{array}{l}\text { Resolution } \\
\text { (m) }\end{array}$ & $\mathrm{n}$ \\
\hline \multirow[t]{2}{*}{1999} & - & Jul 26-Aug 6 & Jul 27-Aug 5 & Lotek LTD $100^{\mathrm{a}}$ & 0.5 & 2 & 0.04 & 7 \\
\hline & & & & $\mathrm{DAR}^{\mathrm{b}}$ & 0.9 & 4 & 0.30 & 4 \\
\hline 2000 & Jul 18-22 & Aug 6-12 & - & & & & & \\
\hline \multirow[t]{3}{*}{2001} & Jul 15-22 & Jul 31-Aug 6 & Jul 30-Aug 6 & Lotek LTD 100 & 0.5 & 2 & 0.04 & 3 \\
\hline & & & & DAR compass ${ }^{\mathrm{b}}$ & 1.1 & 4 & 0.30 & 7 \\
\hline & & & & $\mathrm{PTD}^{\mathrm{c}}$ & 0.7 & 1 & 0.025 & 4 \\
\hline 2002 & Jul 13-18 & Aug 8-12 & - & & & & & \\
\hline \multirow[t]{2}{*}{2003} & Jul 12-18 & Jul 26-Aug 6 & Jul 27-Aug 4 & PTD & 0.7 & 1 & 0.025 & 2 \\
\hline & & & & GPS TDs ${ }^{c}$ & 2.3 & 1 & 0.025 & 8 \\
\hline 2004 & - & Jul 24-Aug 1 & - & & & & & \\
\hline 2005 & Aug $10-14^{\mathrm{d}}$ & Aug 3-11 & Aug 2-11 & GPS TDs ${ }^{c}$ & 2.3 & 1 & 0.025 & 19 \\
\hline
\end{tabular}

We held the university, provincial and federal permits required to capture, equip and mark birds which were treated in accordance with the principles and guidelines of the Canadian Council on Animal Care.

Data analysis for logging devices on gannets. Vertical immersions were considered dives when they were deeper than $1.0 \mathrm{~m}$ (in 1999 and 2001) and $0.3 \mathrm{~m}$ (in 2003 and 2005) owing to differences in the resolution of devices used among years and to eliminate shallower measurements attributed to bathing and preening movements. There were no indications of foraging at the sea surface.

Foraging behaviour was investigated by quantifying the mean percent frequency of dives and mean dive depth per hour over all individuals throughout the $24 \mathrm{~h}$ cycle in a given year. To investigate diurnal diving activity, we first examined the diving activities of each individual separately. We calculated the number of dives that each individual made during each $1 \mathrm{~h}$ time block (e.g. 05:00 = 04:30 to 05:29 h) over all foraging trips, if more than one foraging trip was recorded. To standardize for differing number of dives performed by different individuals, we calculated the percent frequency of dives per $1 \mathrm{~h}$ time block for each individual in each year over the $1 \mathrm{~h}$ time blocks when diving activity was observed, which consistently ranged from 05:00 to 21:00 h each year. Differences in the mean percent dive frequency with time of day and year were examined using a 2-factor ANOVA. Due to non-normal distribution, percent dive frequency data were log transformed prior to analysis. For graphic purposes, we calculated the mean percent dive frequency per $1 \mathrm{~h}$ time block over all individuals in each year. In addition, a chi-squared analysis was conducted to determine if the total number of dives per hour performed by all individuals differed among dawn (1 h: 04:30 to 05:29), daylight (15 h: 05:30 to 20:29), and dusk (1 h: 20:30 to 21:29) periods.

To investigate diurnal patterns in dive depth, we calculated the mean dive depth of each individual per $1 \mathrm{~h}$ time block, combining all foraging trips for each individual. Differences in dive depth with time of day and year were examined over the time blocks when diving activity was observed (05:00 to 21:00 h) using a 2factor ANOVA. Due to non-normal distribution, these data were log transformed prior to analysis. When diving did not occur within a $1 \mathrm{~h}$ time block, this was treated as missing data as opposed to 0. For graphic purposes, we calculated the mean dive depth per $1 \mathrm{~h}$ time block over all individuals in each year. Statistical significance was set at $\alpha=0.05$ and all averages are reported as $\pm 1 \mathrm{SE}$.

Field work on at-sea distributional patterns of gannets and capelin. Distribution of capelin: During the meso-scale survey, signals of fish species were recorded continuously using 3 hydroacoustic systems. The quality of each hydroacoustic system and data processing techniques varied, although they were equally capable of determining the presence or absence of capelin shoals, and distributional patterns. Vessel speed (11 to $14 \mathrm{~km} \mathrm{~h}^{-1}$ ) was held constant throughout all surveys. Short descriptions of the methods are provided here but refer to Davoren et al. (2006) for details and Table 1 for survey dates.

For the 2000 meso-scale survey, a Simrad EQ100 system was operated through a hull-mounted $38 \mathrm{kHz}$ single beam transducer that operated at 1 ping $\mathrm{s}^{-1}$ over a depth range of 8 to $250 \mathrm{~m}$ with a bandwidth of 0.4 to $0.6 \mathrm{~ms}$. The transducer was at a depth of $3 \mathrm{~m}$ and a beam pattern would not form within a range of $5 \mathrm{~m}$; therefore, acoustic signals were not reliable until $8 \mathrm{~m}$. Echograms were continuously printed and latitude and 
longitude were recorded on them every $10 \mathrm{~min}$. The relative abundance of fish was quantified by estimating the percent cover of the prey image in each $250 \mathrm{~m}$ ( 1 min) horizontal by $10 \mathrm{~m}$ vertical bin on the echogram (Piatt 1990). An index of percent cover of prey in each bin was estimated from 0 (no prey) to 9 (nearsaturation). These index values were squared before analysis to account for the non-linear change in sounder intensity relative to fish school density (Piatt 1990), giving a relative measure of acoustic prey abundance.

During the surveys in 2001, 2002 and 2003, a BioSonics DTX 6000 hydroacoustic system calibrated with a tungsten carbide standard target was used. This system operated through a $38 \mathrm{kHz}$ dual beam transducer in a towed body. The transducer was at a depth of $2 \mathrm{~m}$ and a beam pattern would not form within a range of $5 \mathrm{~m}$, therefore, acoustic signals were not reliable until $7 \mathrm{~m}$. The transducer had a 2-way beam angle of $22.671 \mathrm{~dB}$ and the echo sounder was operated at 1 ping $\mathrm{s}^{-1}$ over a depth range of 7 to $500 \mathrm{~m}$, a bandwidth of $5.1 \mathrm{kHz}$ and a pulse duration of $0.4 \mathrm{~ms}$. Raw highresolution acoustic data were recorded continuously. A $\mathrm{S}_{\mathrm{v}}$ threshold of $-63 \mathrm{~dB}$ was applied to the raw data prior to integration and acoustic signals near the bottom that could not be distinguished as biological or due to the ocean floor (dead-zone, side-lobing; Lawson \& Rose 1999) were edited out. The $S_{v}$ in each file was integrated to determine the average aerial backscattering coefficient $\left(\mathrm{S}_{\mathrm{a}}\right)$ for capelin within the water column (MacLennan et al. 2002).

During the fine-scale survey in 2005, the same radial survey was repeated throughout the $24 \mathrm{~h}$ cycle to collect acoustic data on the diel vertical migration (DVM) of capelin. A Simrad EK 500 hydroacoustic system calibrated with a tungsten carbide standard target was used. This system operated through a hull-mounted $38 \mathrm{kHz}$ split-beam transducer, which had a 2-way beam angle of $-20.6 \mathrm{~dB}$ and the echo sounder was operated at 1 ping $\mathrm{s}^{-1}$ over a depth range of 10 to $300 \mathrm{~m}$, a bandwidth of $3.8 \mathrm{kHz}$ and a pulse duration of $1.0 \mathrm{~ms}$. The transducer was at a depth of $4 \mathrm{~m}$ and a beam pattern would not form within a range of $5 \mathrm{~m}$; therefore, acoustic signals were not reliable until $9 \mathrm{~m}$. Raw high-resolution acoustic data were recorded continuously and data processing was similar to that described in the previous paragraph with the exception of applying a threshold of $-80 \mathrm{~dB}$ to the raw data prior to integration.

Distribution of marine birds and mammals: During all acoustic transects, marine birds and mammals were counted continuously by a single observer in a $90^{\circ}$ arc out to $300 \mathrm{~m}$ from the bow to the port side of the ship using the standard strip method of Tasker et al. (1984). Counts with behavioural descriptions (on water, flying, feeding) were entered on a laptop computer with counting software (D. Senciall, Birds \& Beasty Counter, 1998, Fisheries and Oceans Canada, version 1.0) connected to the navigational system of the vessel. A latitude and longitude position was appended to each sighting and location information was used to merge bird and acoustic prey data sets into the smallest spatial bins possible (2000: 250 m; 2001 to 2005: $100 \mathrm{~m}$ ).

Data analysis for at-sea distributional patterns of birds, marine mammals and capelin. To examine whether gannets concentrated in shallow bathymetric areas $(<30 \mathrm{~m})$ where capelin would be accessible throughout the day, we calculated the weighted frequency of occurrence of gannets (flying and on the water) in $10 \mathrm{~m}$ bathymetric bins during the meso-scale survey in each year by dividing the percent frequency of gannets in each bin by the percent frequency at which each bin was surveyed.

To examine whether gannets used marine mammals to access capelin near the surface, we compared the tracking scales of gannets to capelin with gannets to humpback whales Megaptera novaeangliae and minke whales Balaenoptera acutorostrata during meso-scale surveys, using ANOVA. Bivariate statistics based on the neighbour $K$ statistic (Ripley 1981) were used to quantify whether there were significantly more gannets (on the water and flying) associated with acoustic fish signals or whales than would be expected if gannets were distributed randomly within a transect following a quantitative method outlined in detail in numerous publications (O'Driscoll 1998, Davoren 2000, Davoren et al. 2002, 2003). A transect was defined as a period of continuous survey, which consisted of the $12 \mathrm{~h}$ operational d ( 140 km) and the spatial scales analyzed ranged from the smallest spatial resolution (2000: $250 \mathrm{~m} ; 2001$ to 2003: $100 \mathrm{~m}$ ) and increased at increments corresponding to half the length of each transect line $(\sim 70 \mathrm{~km})$. The average number of 'extra' gannets at each prey aggregation, 'extra' gannets at each whale aggregation, or 'extra' whales at each prey aggregation, at each spatial scale was calculated. The scale of maximum association, or 'tracking scale,' of gannets to acoustic fish signals, gannets to whales, or whales to acoustic fish signals was defined as the scale at which the average number of 'extra' gannets or whales was higher than the succeeding 3 values.

\section{RESULTS}

\section{Gannet diets}

The regurgitations of gannets were composed of $>70 \%$ capelin in most years (Fig. 2), with one major exception being 2005 when $87 \%$ of the diet consisted 


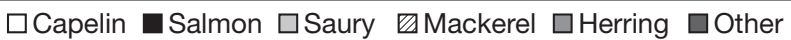

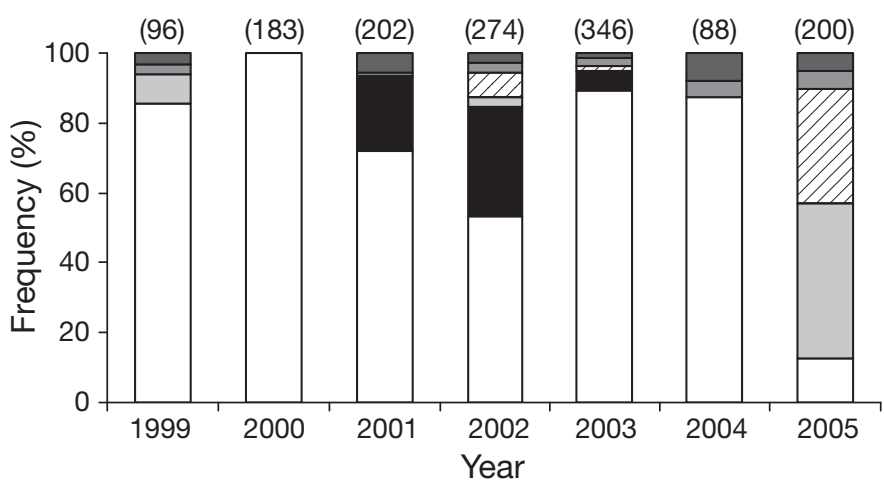

Fig. 2. Sula bassana. Frequency (\%) of prey types in the regurgitations of northern gannets during 1999 to 2005 at Funk Island. Numbers in brackets $=$ total no. of regurgitations examined $\mathrm{yr}^{-1}$. Other: gadoid, squid and mixed-species regurgitations; 1999: capelin-saury; 2001: capelin-salmon, salmonsaury, salmon-herring; 2002: salmon-mackerel, salmon-saury, salmon-squid, salmon-herring, saury- mackerel; 2003: capelinherring, gadid-salmon; 2004: capelin-herring; 2005: capelinherring, capelin-saury, herring-saury, herring-mackerel

of large pelagic fish, mainly mackerel and saury. Food samples obtained upon recaptures for logger retrievals were similar. Regurgitations from loggered birds were comprised of capelin in 1999 ( $\mathrm{n}=5,100 \%$ capelin) and 2003 ( $\mathrm{n}=5,100 \%$ capelin), and other prey were present in 2001 ( $\mathrm{n}=5,60 \%$ capelin, 40\% salmon) and 2005 ( $\mathrm{n}=4,50 \%$ capelin, $25 \%$ saury, $25 \%$ mackerel).

\section{Diel vertical migration (DVM) of capelin}

During the fine-scale survey in 2005, the radial survey was repeated 18 times, resulting in $543 \mathrm{~km}$ of acoustic data on the DVM of capelin. Over the diel light cycle, capelin showed a typical vertical migratory pattern. During daylight hours, distinct capelin shoals were typically concentrated in deep water $(>180 \mathrm{~m})$, with fish ascending toward the surface at dusk (Fig. 3). The ascent took place over approximately $30 \mathrm{~min}$, lasting between 20:40 and 21:10 h local time. During dark hours, capelin remained as a layer of scattered fish (i.e. no distinct shoals) in the top $30 \mathrm{~m}$, with fish forming distinct shoals and descending to deep water at dawn (Fig. 3). Again, the descent took place over approximately $30 \mathrm{~min}$, lasting between 05:10 and 05:40 $\mathrm{h}$ local time (Fig. 3). Therefore, during dark periods (21:10 to $05: 10 \mathrm{~h}$ ), the highest percentage of $S_{a}$ due to capelin was observed in the upper water column $(<30 \mathrm{~m})$, whereas during daylight periods (05:30 to 20:40 h local time) when gannets are primarily feeding, the highest percentage of capelin was found in deeper water
(>180 m). This typical DVM pattern of capelin is consistent with other years in this (Davoren et al. 2006) and other regions (Mowbray 2002) of Newfoundland.

\section{Diurnal dive behaviour of gannets}

Gannets did not dive during dark periods ( 21:30 to 04:29 $\mathrm{h}$ local time; Fig. 4) and the first recorded dive at dawn was similar among years (range: 05:00 to $05: 19 \mathrm{~h}$ ), as was the last recorded dive at dusk (range: 21:05 to 21:23 h). The mean percent dive frequency per hour was generally higher during morning (05:30 to 10:30 h) and evening periods (17:30 to 21:30 h), although these patterns were non-significant and there were no differences among years $\left(F_{65,274}=1.126\right.$, $\mathrm{p}=0.257$; Fig. 4). When all individuals and all years were combined, there were no significant differences in the number of dives per hour among dawn (04:30 to 05:29 h), daylight (05:30 to 20:29 h), and dusk (20:30 to $21: 29 \mathrm{~h})$ periods $\left(\chi^{2}=10.525, \mathrm{df}=6, \mathrm{p}>0.05\right)$. Similarly, diurnal differences in dive depth were not significant, but the mean dive depth was significantly shallower in 2005, when gannets were feeding primarily on large pelagic fish (ANOVA, $F_{66,319}=2.023, \mathrm{p}<0.0001$; Fig. 5) .

\section{At-sea distributional patterns of capelin, gannets and whales}

Although the frequency of gannets was high in areas of shallow water $(<30 \mathrm{~m})$ in most years, high frequencies were found in deeper water (Fig. 6) where capelin would have been inaccessible during daylight. Gannets had significantly tighter spatial associations with whales $(1.6 \pm 0.3 \mathrm{~km})$ over all survey years when compared to capelin in 10 to $50 \mathrm{~m}$ of water $(27.8 \pm 7.7 \mathrm{~km}$; $\left.F_{1,23}=4.411, \mathrm{n}=25, \mathrm{r}=0.401, \mathrm{p}=0.047\right)$. Whales and capelin showed tight associations $(1.2 \pm 0.3 \mathrm{~km})$ over all survey years when whales were present in the study area (Table 2). When whales were not encountered during the meso-scale survey in 2002, there were fewer gannets in the study area and gannets had tighter associations with capelin in the top $50 \mathrm{~m}$, relative to other years (Table 2).

\section{DISCUSSION}

Gannets tended to concentrate in shallow areas $(<30 \mathrm{~m})$, where capelin were accessible at all depths; however, birds also were found in deeper areas. Although diurnal patterns in dive activity were observed for gannets along with diel vertical migratory behaviour of capelin, gannets did not appear to con- 

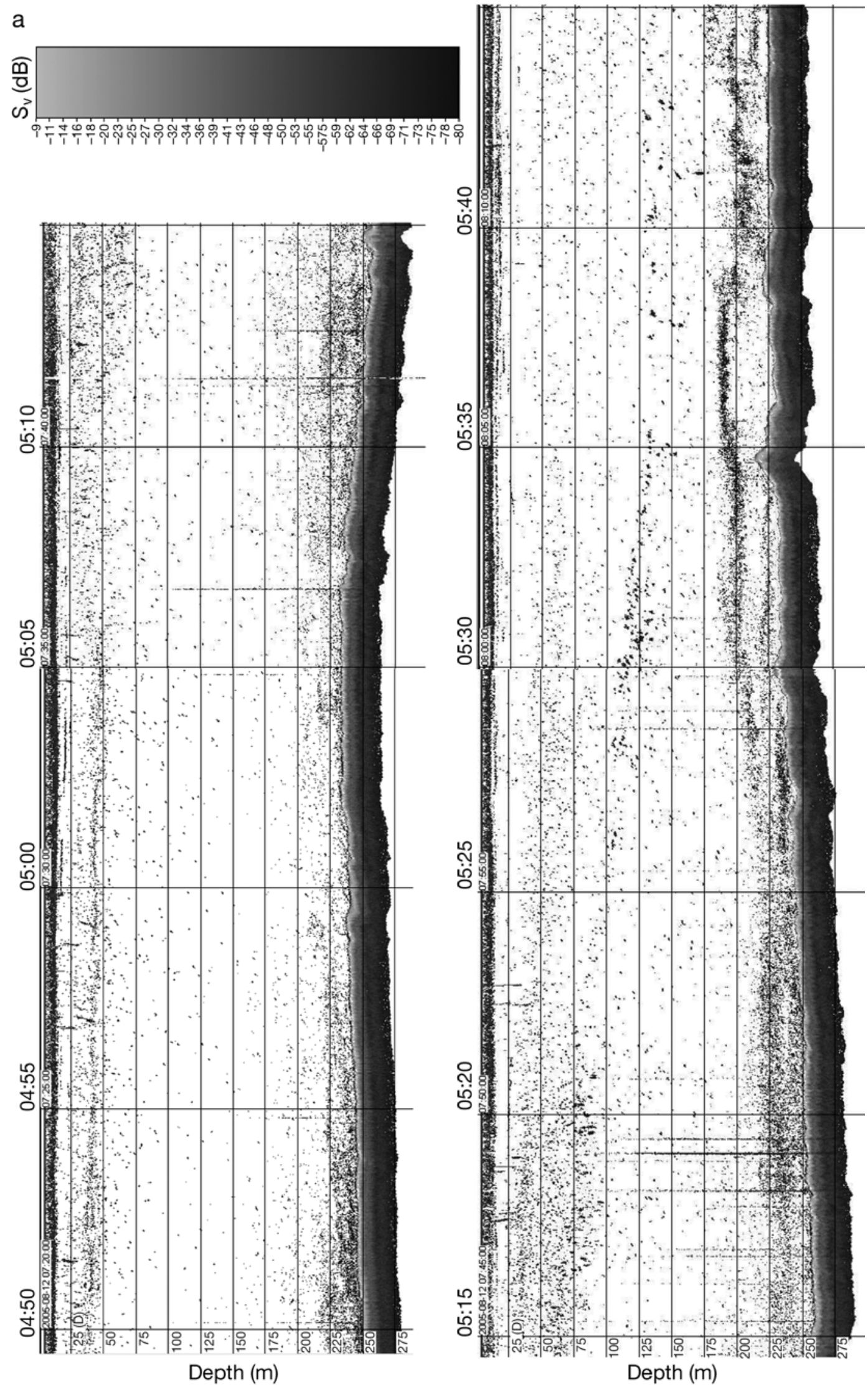

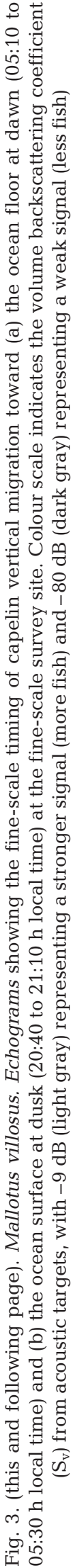



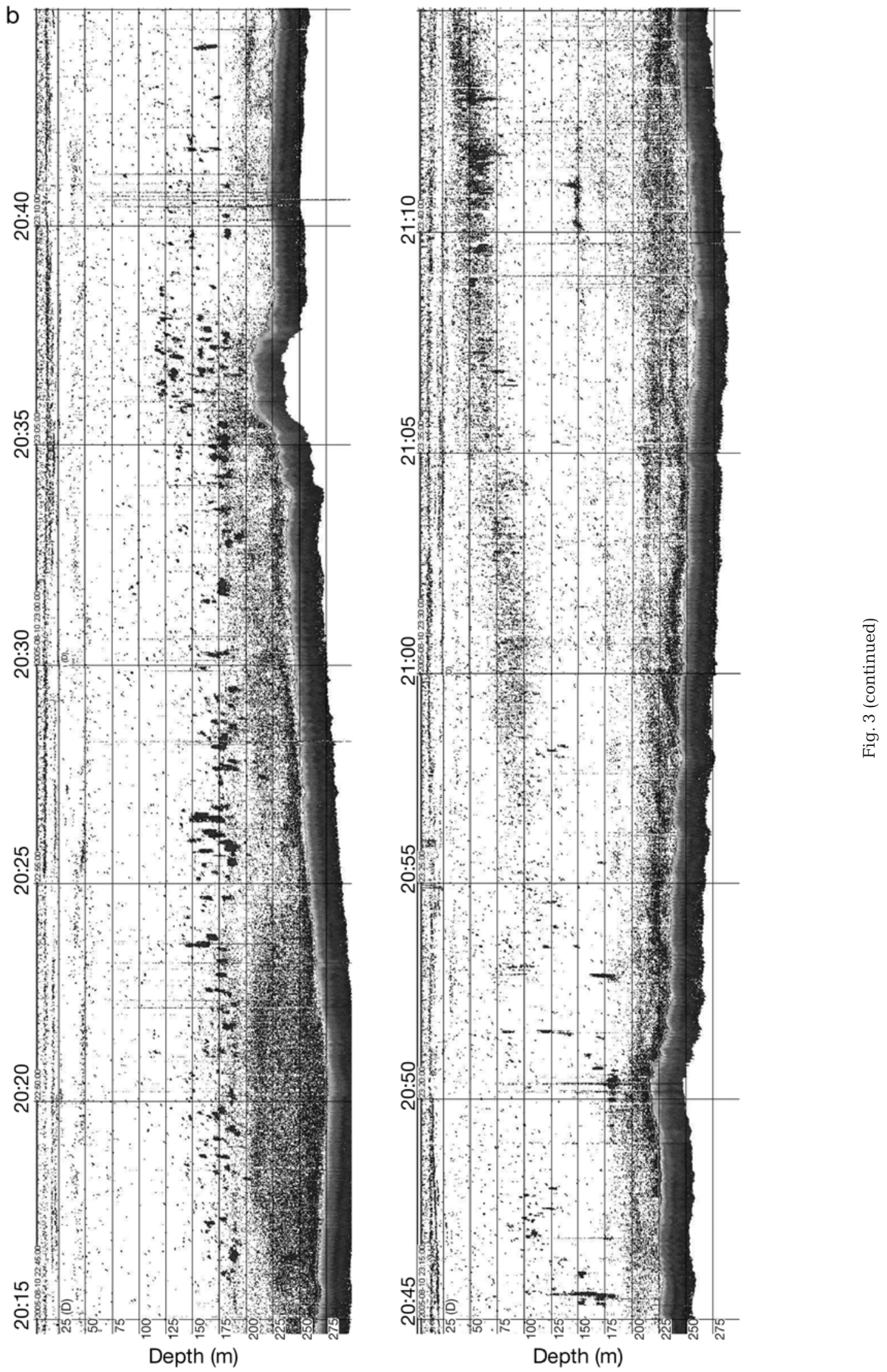

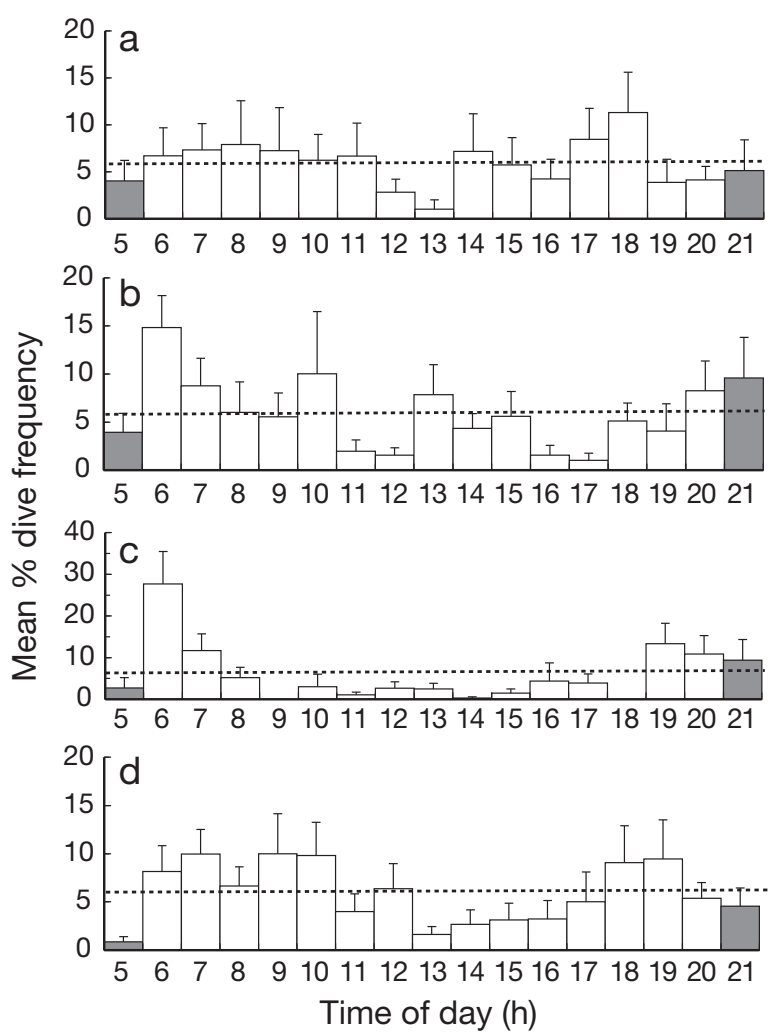

Fig. 4. Sula bassana. Mean dive frequency $(\%, \pm \mathrm{SE})$ of all dives made by parental gannets on all foraging trips during each hour (e.g. 05:00 = 04:30 to 05:29 h) at Funk Island in (a) 1999, (b) 2001, (c) 2003, and (d) 2005. Dashed line: mean $\%$ frequency dives $\mathrm{h}^{-1} \mathrm{yr}^{-1}$; grey bars: transition periods at dawn (05:10 to $05: 40 \mathrm{~h}$ local time) and dusk (20:40 to $21: 10 \mathrm{~h}$ local time). Note the different $y$-axis in (c)

centrate diving effort during dawn and dusk periods, shown by the low mean percent dive frequency during these periods. In addition, there was low temporal overlap (<30 min) in diving activity at dawn and dusk when capelin would have been accessible at the surface. This suggests that gannet diving behaviour is not influenced by the migratory patterns of capelin to a great extent. In contrast, gannets were tightly associated with whales relative to near surface (10 to $50 \mathrm{~m})$ capelin during daylight, which is consistent with results from a previous study (Garthe et al. 2007a). Combined with the tight association of whales and capelin, these results suggest that gannets may successfully track capelin by cueing to the foraging activities of whales.

Foraging in shallow waters $(<30 \mathrm{~m})$ in our study area likely reflects the concentration of foraging effort in areas where capelin are accessible throughout the day. Owing to the persistent aggregations of capelin among years at shallow water $(<30 \mathrm{~m})$ demersal spawning sites in our study area (Davoren et al. 2006), this may also reflect a memory-based foraging strategy. In sup-

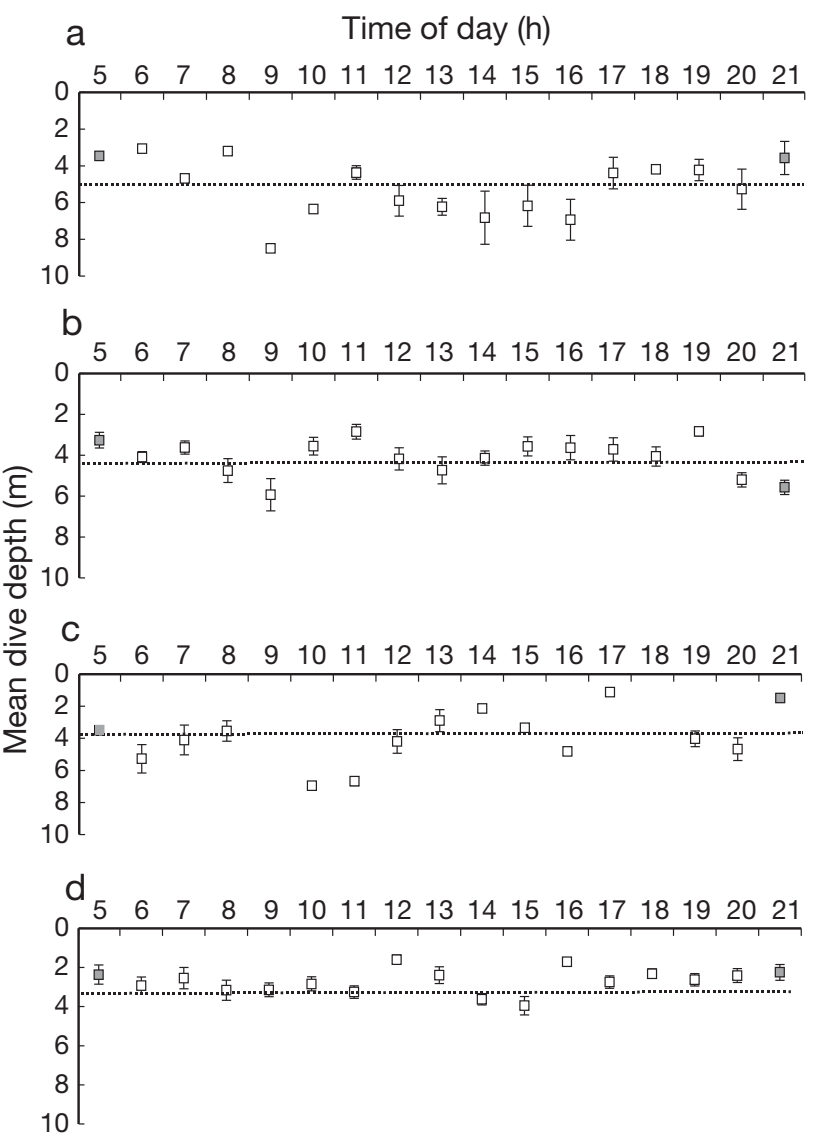

Fig. 5. Sula bassana. Mean maximum depth $( \pm \mathrm{SE})$ of all dives made by parental gannets on all foraging trips during each hour (e.g. 05:00 = 04:30-05:29 h) at Funk Island in (a) 1999 and (b) 2001, (c) 2003, and (d) 2005. Dashed line represents the mean dive depth in each year. Grey as in Fig. 4

port, Garthe et al. (2007a) showed that dive locations of gannets often overlapped with these spawning aggregations of capelin (Davoren 2007). Gannets showed strong foraging area fidelity on a coarse scale for these areas on successive foraging trips, though exact dive locations within areas varied (Garthe et al. 2007a). Similar foraging patterns on successive foraging trips by parental gannets have been observed in our study area (Montevecchi et al. 2009) and in other regions (Hamer et al. 2001). This likely reflects the use of memory on a coarse-scale and network foraging or local enhancement on a finer spatial scale to locate capelin shoals that are accessible during daylight (Wittenberger \& Hunt 1985).

Multispecies feeding assemblages of marine predators have been described throughout the world's oceans (Evans 1982, Hunt et al. 1988, Harrison et al. 1991, Camphuysen \& Webb 1999, Silverman \& Veit 2001) as have the roles of different species in initiating and suppressing (producing and scrounging) these assemblages (Hoffman et al. 1981, Chilton \& Sealy 1987). Foraging whales are thought to be important 

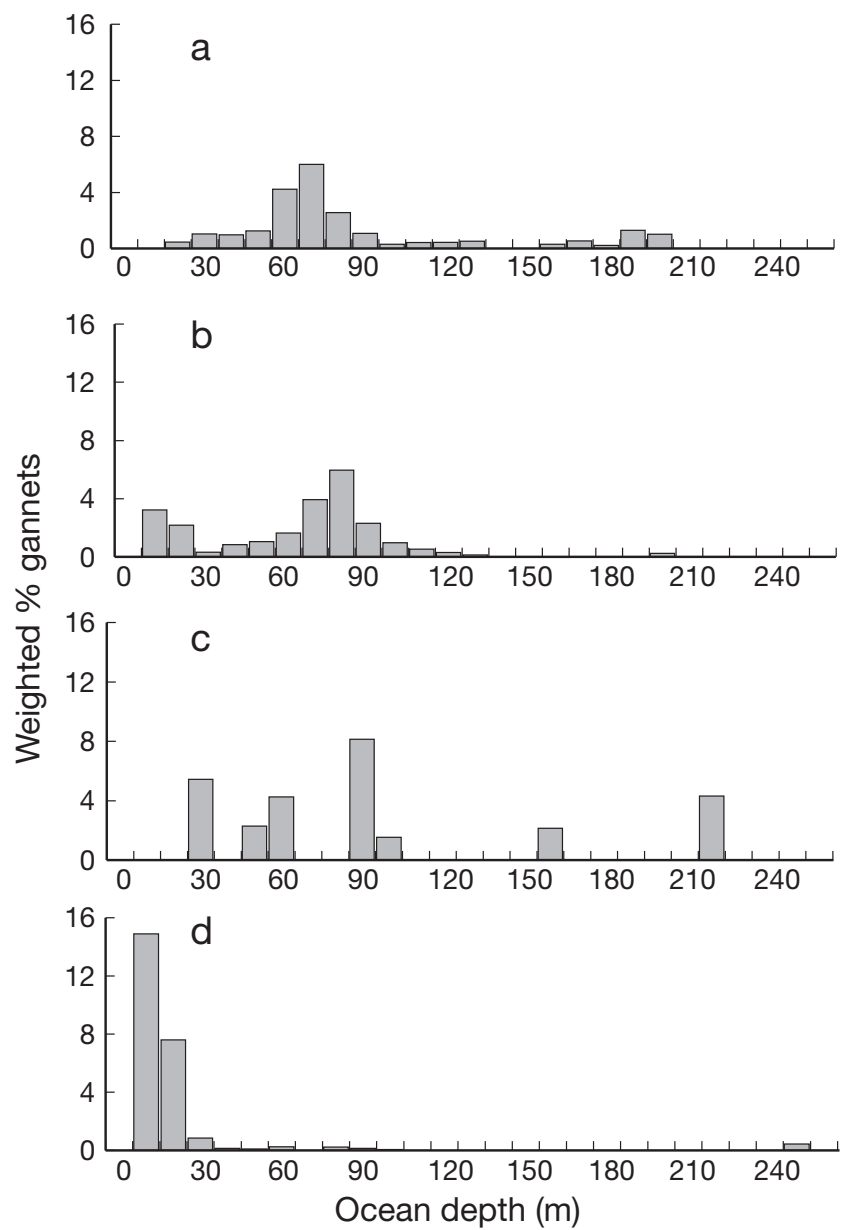

Fig. 6. Sula bassana. Weighted frequency of occurrence (\%) of northern gannets (flying and on the water) in each $10 \mathrm{~m}$ bathymetric bin during each meso-scale survey in mid-late July (a) 2000, (b) 2001, (c) 2002, and (d) 2003

initiators of feeding assemblages of seabirds (Obst \& Hunt 1990) and gannet-cetacean associations, in particular, are well known (Evans 1982, Camphuysen et al. 1995, Camphuysen \& Webb 1999). Cetaceans may function to both minimize the time and energy spent searching for prey as well as bring otherwise inaccessible prey near the ocean surface (Camphuysen et al. 1995, Camphuysen \& Webb 1999). For instance, humpback whales are known to herd schools of forage fish using 'bubble nets' near the ocean surface (Evans 1982, Sharpe \& Dill 1997). Although not directly observed in our study, this is one way whales may increase the accessibility of capelin to gannets. Tracking large predators in general may be a foraging pattern used by gannets. For example, at wintering areas along the SE USA coast, gannets exhibit strong associations with bluefin tuna Thunnus thynnus, apparently as a means of facilitating prey capture (A. M. Boustany pers. comm.).

To our knowledge, despite numerous seabird-whale associations described in the literature, this is the first demonstration that gannets may preferentially track whales rather than prey. Overall, the tighter spatial association of gannets and whales relative to near-

Table 2. Sula bassana, Megaptera novaeangliae, Balaenoptera acutorostrata and Mallotus villosus. Number of northern gannets and whales, proxies of capelin abundance in the top $50 \mathrm{~m}$, and tracking scales of gannets to capelin, gannets to whales, and whales to capelin during the meso-scale surveys in 2000,2001, 2002 and 2003. Numbers in brackets indicate the number of transects $(\sim 140 \mathrm{~km})$ for which tracking scales were calculated (i.e. transects where both gannets and capelin, gannets and whales, or whales and capelin were observed). -: years when no data were collected

\begin{tabular}{|c|c|c|c|c|}
\hline & 2000 & 2001 & 2002 & 2003 \\
\hline Survey length (km) & 610 & 431 & 373 & 517 \\
\hline $\begin{array}{l}\text { No. of gannets } \\
\% \text { flying } \\
\% \text { plunge diving } \\
\% \text { sitting on the water } \\
\text { Mean } \pm \text { SE no. of gannets per } \mathrm{km}\end{array}$ & $\begin{array}{c}685 \\
65 \\
1 \\
34 \\
0.13 \pm 0.03\end{array}$ & $\begin{array}{c}962 \\
70 \\
1 \\
29 \\
0.10 \pm 0.01\end{array}$ & $\begin{array}{c}220 \\
94 \\
0 \\
6 \\
0.03 \pm 0.01\end{array}$ & $\begin{array}{c}1191 \\
30 \\
1 \\
69 \\
0.23 \pm 0.12\end{array}$ \\
\hline No. of whales & 31 & 25 & 0 & 7 \\
\hline $\begin{array}{l}\text { No. of capelin shoals }<50 \mathrm{~m} \\
\text { Total horizontal distance of capelin shoals }<50 \mathrm{~m}(\mathrm{~km}) \\
\text { Mean } \pm \text { SE width of shoals }<50 \mathrm{~m}(\mathrm{~m})\end{array}$ & $\begin{array}{c}79 \\
5.7 \\
71.8 \pm 13.9\end{array}$ & $\begin{array}{c}206 \\
12.0 \\
58.3 \pm 3.8\end{array}$ & $\begin{array}{c}38 \\
13.0 \\
341.4 \pm 98.5\end{array}$ & $\begin{array}{c}49 \\
4.5 \\
90.8 \pm 16.8\end{array}$ \\
\hline $\begin{array}{l}\text { Tracking scale: gannets-capelin }(<50 \mathrm{~m}) \\
\text { Mean } \pm \text { SE }(\mathrm{km}) \\
\text { Range }(\mathrm{km})\end{array}$ & $\begin{array}{c}33.4 \pm 22.4(5) \\
7.8-122.8\end{array}$ & $\begin{array}{c}33.9 \pm 12.9(6) \\
4.9-84.3\end{array}$ & $\begin{array}{c}13.3 \pm 3.2(4) \\
5.3-16.9\end{array}$ & $\begin{array}{c}25.5 \pm 16.6(3) \\
4.3-58.2\end{array}$ \\
\hline $\begin{array}{l}\text { Tracking scale: gannets-whales } \\
\text { Mean } \pm \mathrm{SE}(\mathrm{km}) \\
\text { Range }(\mathrm{km})\end{array}$ & $\begin{array}{c}1.7 \pm 0.5(4) \\
0.8-2.8\end{array}$ & $\begin{array}{c}1.4 \pm 0.8(2) \\
0.6-2.1\end{array}$ & $\begin{array}{l}-(0) \\
-\end{array}$ & $\begin{array}{l}1.6(1) \\
1.6\end{array}$ \\
\hline $\begin{array}{l}\text { Tracking scale: whales-capelin (total) } \\
\text { Mean } \pm \text { SE }(\mathrm{km}) \\
\text { Range }(\mathrm{km})\end{array}$ & $\begin{array}{c}1.4 \pm 0.6(5) \\
0.5-3.8\end{array}$ & $\begin{array}{c}1.0 \pm 0.2(3) \\
0.6-1.3\end{array}$ & $\begin{array}{l}-(0) \\
-\end{array}$ & $\begin{array}{c}1.1 \pm 0.4(2) \\
(0.7-1.4)\end{array}$ \\
\hline
\end{tabular}


surface capelin shoals, combined with the tight spatial association of whales and capelin, suggest that gannets may successfully track capelin by cueing to the foraging activities of whales.

Breeding gannets can also offset energy expenditure during foraging in a number of other ways. First, gannets can switch prey species and sizes captured (Montevecchi \& Myers 1997, Hamer et al. 2000). Gannets tend to prefer large pelagic fish, as their dietary composition reflects the presence or absence of these fish within foraging ranges (Montevecchi \& Myers 1995, Montevecchi 2007). Capelin comprise the bulk of the diet when large pelagic fish are absent (Montevecchi et al. 2005). Second, gannets appear to alter dive shape (U- versus V-shaped dives; Garthe et al. 2000), dive depth (this study) and foraging ranges (Garthe et al. 2007b) when capturing different prey types. For instance, the shallower mean dive depth in 2005 corresponds with the higher percentage of large pelagic fish $(80 \%)$ in their diets. This also corresponds to concentrating foraging activity primarily in shallow water areas. By switching from flapping flight (high energetic costs) to gliding flight (lower energetic costs; BirtFriesen et al. 1989) gannets can increase foraging ranges without much more energy expenditure relative to other more heavily wing-loaded species (e.g. murres; Monaghan et al. 1994). Along with recent reductions in human-induced mortality, this behavioural flexibility supports the increasing trends in gannet populations (Montevecchi \& Myers 1997, Montevecchi et al. 2009).

Although gannets appeared to concentrate foraging effort in early morning and late evening, these trends were not significant and peaks occurred after capelin had migrated to inaccessible depths. Although endothermic, air-breathing predators are known to dive to shallower depths during dark periods when foraging for prey that undergo regular DVM (Croxall et al. 1985, Kooyman et al. 1992, Williams et al. 1992, Pütz et al. 1998, Georges et al. 2000), these dives appear to result in low ingestion rates (Wilson et al. 1993). This is supported by the lack of foraging activity by gannets under low light conditions, including dark, dawn and dusk transition periods $\left(<1 \mu\right.$ Einsteins $\left.\mathrm{m}^{-2} \mathrm{~s}^{-1}\right)$, beginning only after light levels had increased ( 8 $\mu$ Einsteins $\mathrm{m}^{-2} \mathrm{~s}^{-1}$; G.K.D. unpubl. data), as has been found in other studies (Wanless et al. 1999). In addition, the dispersion of near-surface capelin at dawn and dusk may also reduce capture rates. Although we did not measure ingestion rates, the similar number of dives per hour throughout dawn, dusk and daylight periods suggests that foraging success may be comparable throughout the period that gannets dive. The lower percent dive frequency at dawn and dusk compared to other daylight periods along with the low temporal overlap (<30 min) of diving activity with near-surface capelin at dusk and dawn, suggest that the diel vertical migratory patterns of capelin have little influence on gannet foraging activities. Alternately, capelin migratory patterns likely have a stronger influence on foraging strategies of other avian predators in the study area, specifically the common murre Uria aalge, that relies primarily on capelin as prey (Davoren \& Montevecchi 2003) and forages throughout the diel cycle (Hedd et al. 2009).

Diurnal trends in diving activity may instead result from physiological processes related to digestion or provisioning behaviour. Gannets spend extended rest periods on the sea surface during foraging trips (Garthe et al. 2003, Lewis et al. 2004, Ropert-Coudert et al. 2004), which are thought to allow the digestion of ingested prey. Owing to time needed to digest prey, parents may concentrate foraging efforts during the evening, so that periods of digestion overlap with the imposed non-foraging dark period (Garthe et. al. 2003, Ropert-Coudert et al. 2004). In support, parents that depart the colony later in the day, typically stay at sea overnight and concentrate foraging activity just before dark (Garthe et al. 2003). The concentration of foraging effort in the morning could be to obtain food for the chick before returning to the colony (Garthe et al. 2003).

\section{CONCLUSION}

The diel vertical migration of prey is an obvious explanation for observed diurnal foraging patterns of marine predators. Few studies, however, have tested this by directly comparing the fine-scale timing of vertical movement patterns of prey and predator foraging activities (Croxall et al. 1985). By doing this, we found that despite diurnal trends in the foraging activities of an opportunistic marine avian predator, these do not appear to reflect the accessibility of near-surface forage prey at dawn and dusk. Instead, predators appeared to use memory of temporally and spatially predictable aggregations of accessible prey and local enhancement associated with conspecific and marine mammals. By employing this mixed strategy, predators apparently combine advantages of increased light during daylight and decreased energy required to locate near-surface capelin aggregations, thus allowing high foraging efficiency.

There is growing evidence for consistent habitat use by marine predators, reflected by regular concentration in 'hot spots', as well as memory-based foraging tactics, where bird-borne position loggers reflect animals returning to the same fine and coarse-scale regions within and among years. A mixed strategy of 
memory-based foraging tactics combined with local enhancement likely minimizes energetically costly search activities for prey in a dynamic patchy environment. This is especially notable during periods of high energetic demands, such as breeding or moulting.

Acknowledgements. Principal funding was provided by NSERC Post-Doctoral Fellowship to G.K.D., NSERC Discovery and Strategic Project Grants to G.K.D and W.A.M., with further support from the Research and Technology Centre in Büsum, the German Research Foundation (DFG Ga 617/1 to S.G.), the Memorial University of Newfoundland, the University of Manitoba and the Italian Ministero dell'Università e della Ricerca Scientifica e Tecnologica. Ship time funding was provided by NSERC and Fisheries and Oceans Canada for work aboard the CCGS 'Wilfred Templeman' and 'Shamook'. The Newfoundland and Labrador Parks Division permitted us to work in the Funk Island Ecological Seabird Reserve. Special thanks goes to Captain L. Easton, family and crew for safely commuting us to and from Funk Island. We gratefully acknowledge A. D. Murphy for directing, operating and managing technical equipment and electronic data aboard the CCGS 'Shamook'. Thanks to A. Hedd, C. May, C. Burke, J. Anderson, E. MacDonald, G. Redmond, D. Davis, E. Dalley, C. Lang, F. Mowbray, and the captain and crews of the CCGS 'Wilfred Templeman' and 'Shamook' for assistance with field work.

\section{LITERATURE CITED}

Adams NJ, Walter CB (1993) Maximum diving depths of cape gannets. Condor 95:734-736

Birt-Friesen VL, Montevecchi WA, Cairns DK, Macko SA (1989) Activity-specific metabolic rates of free-living northern gannets and other seabirds. Ecology 70:357-367

Brierley AS, Fernandes PG (2001) Diving depths of northern gannets: acoustic observations of Sula bassana from an autonomous underwater vehicle. Auk 118:529-534

Camphuysen CJ, Webb A (1999) Multi-species feeding associations in North Sea seabirds: jointly exploiting a patchy environment. Ardea 87:177-198

Camphuysen CJ, Heessen HJL, Winter CJN (1995) Distant feeding and associations with cetaceans of gannets Morus bassanus from the Bass Rock in May 1994. Seabird 17: $36-43$

Chilton G, Sealy SG (1987) Species roles in mixed-species feeding flocks of seabirds. J Field Ornithol 58:456-463

> Croxall JP, Everson I, Kooyman GL, Ricketts C, Davis RW (1985) Fur seal diving behaviour in relation to vertical distribution of krill. J Anim Ecol 54:1-8

> Davoren GK (2000) Variability in foraging in response to changing prey distributions in rhinoceros auklets. Mar Ecol Prog Ser 198:283-291

Davoren GK (2007) Effects of gill-net fishing on marine birds in a biological hotspot in the Northwest Atlantic. Conserv Biol 21:1032-1045

> Davoren GK, Montevecchi WA (2003) Signals from seabirds indicate changing biology of capelin stocks. Mar Ecol Prog Ser 258:253-261

- Davoren GK, Montevecchi WA, Anderson JT (2002) Scaledependent associations of predators and prey: constraints imposed by flightlessness of common murres. Mar Ecol Prog Ser 245:259-272

$>$ Davoren GK, Montevecchi WA, Anderson JT (2003) Distributional patterns of a marine bird and its prey: habitat selec- tion based on prey and conspecific behaviour. Mar Ecol Prog Ser 256:229-242

Davoren GK, Anderson JT, Montevecchi WA (2006) Shoal behavior and maturity relations of spawning capelin (Mallotus villosus) off Newfoundland: demersal spawning and diel vertical movement patterns. Can J Fish Aquat Sci 63: 268-284

> Davoren GK, Buren A, Burke C, May C and others (2007) An ecosystem-based research program for capelin (Mallotus villosus) in the Northwest Atlantic: overview and results. J Northwest Atl Fish Sci 39:35-48

Evans PGH (1982) Associations between seabirds and cetaceans: a review. Mammal Rev 12:187-206

> Garthe S, Hüppop O (1994) Distribution of ship-following seabirds and their utilization of discards in the North Sea in summer. Mar Ecol Prog Ser 106:1-9

Garthe S, Grémillet D, Furness RW (1999) At-sea-activity and foraging efficiency in chick-rearing Northern Gannets Morus bassanus: a case study in Shetland. Mar Ecol Prog Ser 185:93-99

Garthe S, Benvenuti S, Montevecchi WA (2000) Pursuitplunging by gannets (Morus bassanus) feeding on capelin (Mallotus villosus). Proc Biol Sci 267:1717-1722

Garthe S, Benvenuti S, Montevecchi WA (2003) Temporal patterns of foraging activities of northern gannets Morus bassanus in the north-west Atlantic. Can J Zool 81: $453-461$

Garthe S, Montevecchi WA, Davoren GK (2007a) Flight destinations and foraging behavior of northern gannets preying on a small forage fish in a Low Arctic ecosystem. Deep-Sea Res II 54:311-320

Garthe S, Montevecchi WA, Chapdelaine G, Rail JF, Hedd A (2007b) Contrasting foraging tactics by northern gannets in different oceanographic domains with different prey fields. Mar Biol 151:687-694

Georges JY, Tremblay Y, Guinet C (2000) Seasonal diving behaviour in lactating subantarctic fur seals on Amsterdam Island. Polar Biol 23:59-69

> Hamer KC, Phillips RA, Wanless S, Harris MP (2000) Foraging ranges, diets and feeding locations of gannets Morus bassanus in the North Sea. Mar Ecol Prog Ser 200: $257-264$

> Hamer KC, Phillips RA, Hill JK, Wanless S, Wood AG (2001) Contrasting foraging strategies of gannets Morus bassanus at two North Atlantic colonies: foraging trip duration and foraging area fidelity. Mar Ecol Prog Ser 224: 283-290

Harrison NM, Whitehouse MJ, Heinemann D, Prince PA, Hunt GL Jr, Veit RR (1991) Observations of multispecies seabird flocks around South Georgia. Auk 108:801-810

Hays GC (2003) A review of the adaptive significance and ecosystem consequences of zooplankton diel vertical migrations. Hydrobiologia 503:163-170

Hedd A, Regular PM, Montevecchi WA, Buren AD, Burke CM, Fifield DA (2009) Going deep: common murres dive into frigid water for aggregated, persistent and slowmoving capelin. Mar Biol 156:741-751

Hoffman W, Heinemann D, Wiens JA (1981) The ecology of seabird feeding flocks in Alaska. Auk 98:437-456

Hunt GL Jr, Harrison NM, Hamner WM, Obst BS (1988) Observations of a mixed-species flock of birds foraging on euphausiids near St. Matthew Island, Bering Sea. Auk 105:345-349

Kooyman GL, Cherel Y, Le Maho Y, Croxall JP, Thorson PH, Ridoux V, Kooyman CA (1992) Diving behavior and energetics during foraging cycles in king penguins. Ecol Monogr 62:143-163 
Lawson GL, Rose GA (1999) The importance of detectability to acoustic surveys of semi-demersal fish. ICES J Mar Sci $56: 370-380$

Lewis S, Benvenuti S, Dall'Antonia L, Griffiths R and others (2002) Sex-specific foraging behaviour in a monomorphic seabirds. Proc Biol Sci 269:1687-1693

Lewis S, Benvenuti S, Daunt F, Wanless S and others (2004) Partitioning of diving effort in foraging trips of northern gannets. Can J Zool 82:1910-1916

MacLennan DN, Fernandes PG, Dalen J (2002) A consistent approach to definitions and symbols in fisheries acoustics. ICES J Mar Sci 59:365-369

Monaghan P, Walton P, Wanless S, Uttley JD, Burns MD (1994) Effects of prey abundance on the foraging behaviour, diving efficiency and time allocation of breeding guillemots Uria aalge. Ibis 136:214-222

Montevecchi WA (2007) Binary responses of northern gannets Morus bassanus to changing food web and oceanographic conditions. Mar Ecol Prog Ser 352:213-220

Montevecchi WA, Myers RA (1995) Prey harvests of seabirds reflect pelagic fish and squid abundance on multiple spatial and temporal scales. Mar Ecol Prog Ser 117:1-9

Montevecchi WA, Myers RA (1996) Dietary changes of seabirds reflect shifts in pelagic food webs. Sarsia 80: 313-322

Montevecchi WA, Myers RA (1997) Centurial and decadal oceanographic influences on changes in Northern Gannet populations and diets in the northwest Atlantic: implications for climate change. ICES J Mar Sci 54:608-614

Montevecchi WA, Garthe S, Davoren GK (2005) Biophysical influences on seabird trophic assessments. In: Boyd L, Wanless $\mathrm{S}$, Camphuysen CJ (eds) Top predators in marine ecosystems. Cambridge University Press, Cambridge, p 118-130

Montevecchi WA, Benvenuti S, Garthe S, Davoren GK, Fifield D (2009) Flexible foraging tactics by a large opportunistic seabird preying on forage- and large pelagic fishes. Mar Ecol Prog Ser 385:295-306

Mowbray F (2002) Changes in the vertical distribution of capelin (Mallotus villosus) off Newfoundland. ICES J Mar Sci 59:942-949

Nelson JB (1978) The gannet. T \& AD Poyser, Berkhamsted

Norse EA, Crowder LB, Gjerde K, Hyrenbach D, Roberts CM, Safina C, Soulé ME (2005) Place-based ecosystem management in the open ocean. In: Norse EA, Crowder LB (eds) Marine conservation biology: the science of

Editorial responsibility: John Piatt, Anchorage, Alaska, USA maintaining the sea's biodiversity. Island Press, Washington, DC p 302-327

O'Driscoll RL (1998) Description of spatial pattern in seabird distributions along line transects using neighbour K statistics. Mar Ecol Prog Ser 165:81-94

Obst BS, Hunt GL Jr (1990) Marine birds feed at gray whale mud plumes in the Bering Sea. Auk 107:678-688

Piatt JF (1990) The aggregative response of common murres and Atlantic puffins to schools of capelin. Stud Avian Biol 14:36-51

Porter JM, Sealy SG (1982) Dynamics of seabird multispecies feeding flocks: age-related feeding behaviour. Behaviour 81:91-109

Pütz K, Wilson RP, Charrassin JB, Raclot T and others (1998) Foraging strategy of king penguins (Aptenodytes patagonicus) during summer at the Crozet Islands. Ecology 79:1905-1921

Ripley BD (1981) Spatial statistics. Wiley, New York

> Ropert-Coudert Y, Gre'millet D, Ryan PG, Kato A, Naito Y, Le Maho Y (2004) Between air and water: the plunge dive of the cape gannet Morus capensis. Ibis 146:281-290

> Sharpe FA, Dill LM (1997) The behaviour of Pacific herring schools in response to artificial humpback whale bubbles. Can J Zool 75:725-730

Silverman ED, Veit RR (2001) Associations among Antarctic seabirds in mixed-species feeding flocks. Ibis 143:51-62

Tasker ML, Jones PH, Dixon T, Blake BF (1984) Counting seabirds at sea from ships: a review of methods employed and a suggestion for a standardized approach. Auk 101: 567-577

Wanless S, Finney SK, Harris MP, McCafferty DJ (1999) Effect of the diel light cycle on the diving behaviour of two bottom feeding marine birds: the blue-eyed shag Phalacrocorax atriceps and the European shag P. aristotelis. Mar Ecol Prog Ser 188:219-224

Williams TD, Kato A, Croxall JP, Naito Y, Briggs DR, Rodwell S, Barton TR (1992) Diving pattern and performance in nonbreeding Gento penguins (Pygoscelis papua) during winter. Auk 109:223-234

Wilson RP, Puetz K, Bost CA, Culik BM, Bannasch R, Reins T, Adelung D (1993) Diel dive depth in penguins in relation to diel vertical migration of prey: whose dinner by candlelight? Mar Ecol Prog Ser 94:101-104

Wittenberger JF, Hunt GL (1985) The adaptive significance of coloniality in birds. Avian Biol 8:1-77

Submitted: October 10, 2008; Accepted: October 12, 2009

Proofs received from author(s): March 20, 2010 